\title{
Seasonal Movements of Juvenile and Adult Herring (Clupea harengus L.) Tagged Along the Maine and New Hampshire Coasts in 1976-82
}

\author{
Edwin P. Creaser and David A. Libby \\ Maine Department of Marine Resources \\ Fisheries Research Laboratory \\ West Boothbay Harbor, Maine, USA 04575
}

\begin{abstract}
Between 1976 and 1982, 164,128 juvenile and adult herring were tagged and released at 72 sites along the Maine and New Hampshire coasts. Total recovery rates were $5.9 \%$ for juveniles and $4.9 \%$ for adults. Effective recovery rates (i.e. from the 15 th day after release) were 4.1 and $3.5 \%$. respectively. Migration patterns varied with season and region of tagging. Summer-feeding juveniles from all areas along the coast frequently moved into adjacent areas during the $3 \mathrm{rd}$ and the 4 th calendar quarters. Some of these juveniles then underwent an autumn migration to the southwest where they overwintered off the Massachusetts and New Hampshire coasts. Others overwintered off southwestern and northeastern Maine. There was a tendency for tagged fish to be recaptured east of the tagging site during the 2 nd and 3 rd quarters of the following year. Tagging studies on summer-feeding adults showed migration patterns similar to juveniles. There was a small but consistent tendency for some adult fish tagged in eastern Maine to be recovered in the Southwest Nova Scotian fishery. There was no evidence of changes in seasonal migration patterns of either juveniles or adults during the study period. Tagging studies on overwintering juveniles tagged in northeastern Maine showed that most recoveries during the following year were from the tagging area. Tagging studies on spawning herring tagged off New Hampshire and northeastern Maine showed that these fish overwinter off Massachusetts. Recoveries during the 3rd and 4th calendar quarters of the following year were in close proximity to the tagging area.
\end{abstract}

\section{Introduction}

Herring tagging studies were first conducted by the Maine Department of Marine Resources (D.M.R.) between 1976-78 when 57,887 age 2+ herring were tagged and released at 34 sites along the Maine coast (Creaser et al., 1984). These studies were continued between 1980-82, when an additional 106,241 age $2^{+}$ herring were tagged and released at 38 sites along the Maine and New Hampshire coasts.

This manuscript summarizes the results of all herring tagging studies conducted by D.M.R. between 1976 and 1982 except those tagging studies on age 1 juveniles already reported (Creaser and Libby, 1986). Overall objectives were to investigate (a) seasonal migration patterns of juvenile and adult herring over time, (b) the extent of their movement into Canadian and Massachusetts waters, and (c) the occurrence in other geographical areas (fisheries) of adults tagged in Maine coastal waters. It was also anticipated that the results of these studies might yield some useful information in defining herring stocks in the Gulf of Maine. Movement patterns of some seasonal behavior categories presented here have not been reported by Creaser et al. (1984). Other movement patterns presented confirm earlier findings.

\section{Materials and Methods}

\section{Tagging procedures}

In most respects, the procedures used in locating, holding, and tagging herring ware similar to those reported previously (Creaser and Libby, 1986). One change involved the use of two smaller holding pockets in place of one larger pocket to simplify towing the nets over seine cork lines. Another change involved the transfer of fish from the fisherman's holding pocket to our holding pocket; fish were bailed with dip nets instead of submerging the cork lines and coaxing them to swim from one to the other.

Juveniles and adult herring were tagged with Floy FD-68B yellow T-bar spaghetti tags. The change from Floy FD-67 used in 1976-78 was implemented because the FD-68B have a slightly better retention rate on largemouth bass, Micropterus salmoides (Tranquilli and Childers, 1982). Tag construction is described in Creaser and Libby (1986). Tags were attached by means of Dennison Mark II Swiftacker guns (Dennison Co., Framingham, Massachusetts) equipped with standard needles ( $2 \mathrm{~mm}$ outside diameter).

Tagging locations during the 1976-78 studies have 
been presented in Creaser et al. (1984). Tagging locations for the 1980-82 studies are shown in Fig. 1. Tagging regions established for the analysis of herring tag release and recovery data (Stobo, 1983), are shown in Fig. 2. Tags and recovery information were obtained from herring processing facilities in Massachusetts,

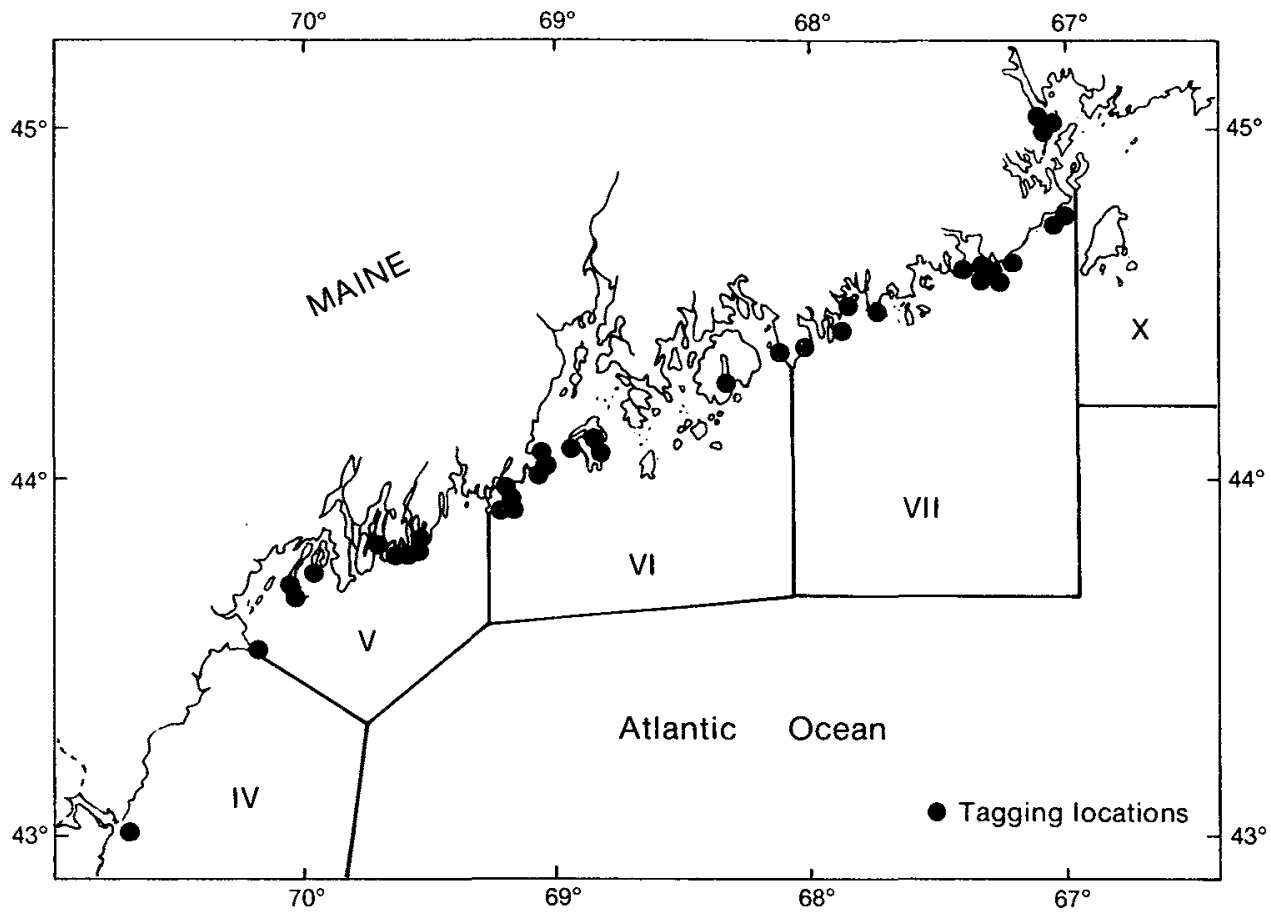

Fig. 1. Tagging locations for juvenile and adult herring tagged along the Maine and New Hampshire coasts during 1980-82.

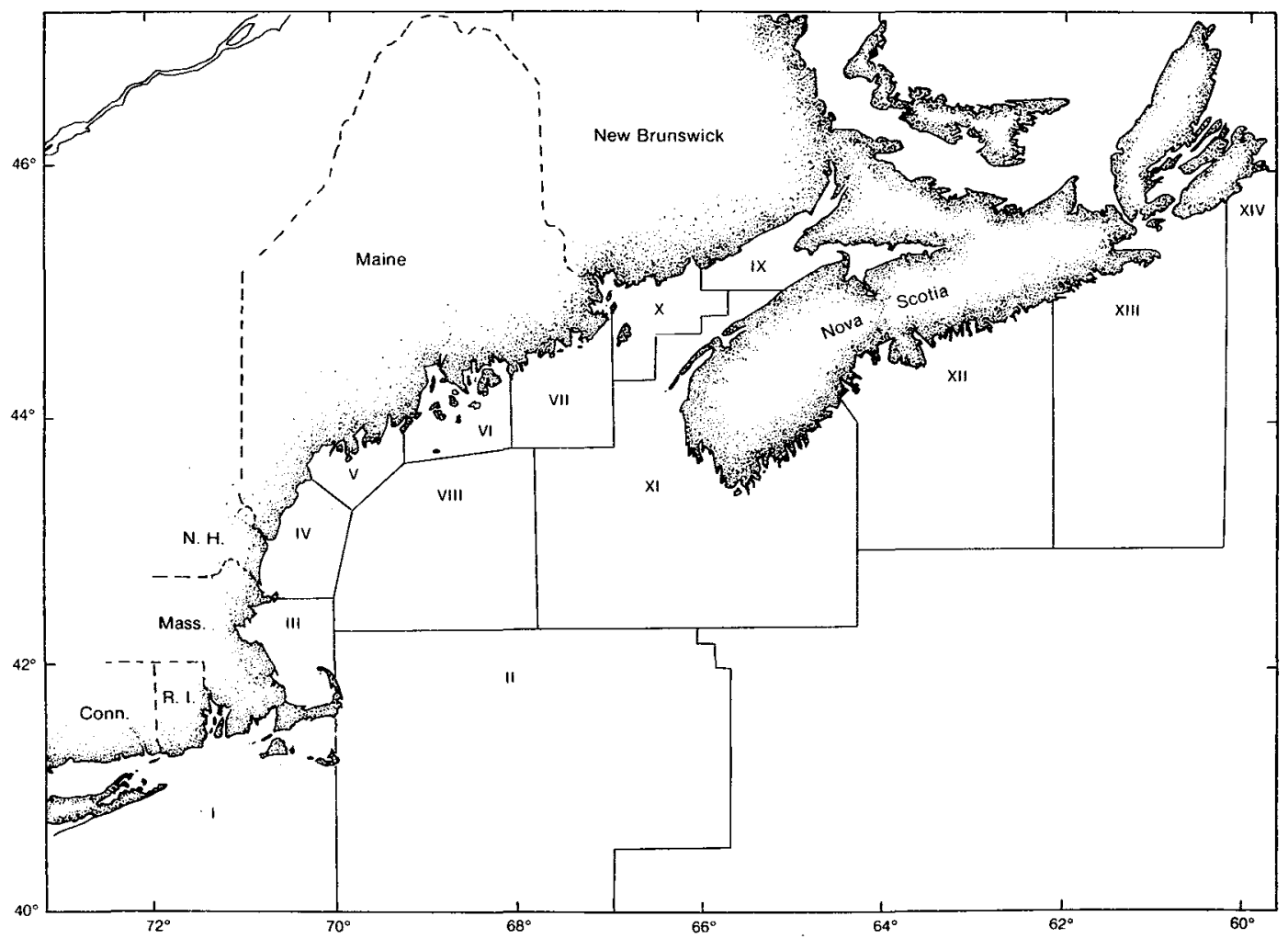

Fig. 2. Regions (I-XIV) established for the analysis of data on herring tag releases and recoveries off the Atlantic coasts of southern Canada and northeastern United States. 
Maine, New Brunswick, and Nova Scotia. The tagging program was widely publicized and a reward of $\$ 1.00$ (1976-78) and $\$ 3.00$ after 1980 was paid for each tag returned. A sample of 50-250 herring was randomly collected during each tagging study and measured for length. Age was determined from a sample of 15-150 fish. Information on the sex composition and stage of sexual maturity was only compiled for fish $>23 \mathrm{~cm}$ length because fish smaller than this can safely be assumed to be immature. The eight stages of sexual maturity are listed by Boyar (1968).

\section{Analysis of tagging data}

Tag release and recovery regions, seasonal behavior categories, the criteria for grouping tagged lots into juvenile or adult categories, and the criteria for presenting recoveries as "total" or "effective" are the same as reported by Creaser et al. (1984). The four calendar quarters (1. Jan to Mar; 2. Apr to Jun; 3. Jul to Sep; 4. Oct to Dec), approximate winter, spring, summer, and autumn respectively. In a few cases, juvenile herring tagged prior to 1 July were included with summer feeding juveniles because there was no indica- tion they were spring migrating fish and subsequent tag recoveries revealed that the fish were tagged in the same area where they were later recovered during summer feeding.

Information on numbers tagged and recovered, length, age, sex, and stage of maturity, collected during the 1976-78 tagging studies, has been presented by Creaser et al. (1984). Similar information for the 1980-82 studies is presented in this paper. Unadjusted tag recovery results from 1976 to 1978 (Creaser et al., 1984) and 1980-82 studies, have both been adjusted for landings, by region and calendar quarter, and expressed as numbers of tags recovered per 1,000 metric tons landed to assure consistency in the interpretation of results. The actual number of tags returned by region and calendar quarter can be calculated from these adjusted recoveries and the landings recorded by region and calendar quarter (Table 1). Landings from regions I-VII were obtained from the National Marine Fisheries Center (Northeast Fisheries Center, Woods Hole, Massachusetts) and landings from regions X-XIV were obtained from the Canadian Department of Fisheries and Oceans (St. Andrews, New Brunswick).

TABLE 1. Herring landings (metric tons) in regions I-XIII reported by calendar quarters during 1976-84.

\begin{tabular}{|c|c|c|c|c|c|c|c|c|c|c|}
\hline \multirow[b]{2}{*}{ Year } & \multirow[b]{2}{*}{ Quarters } & \multicolumn{9}{|c|}{ Landings by region } \\
\hline & & 1 & III & $\mathrm{IV}^{*}$ & $V^{*}$ & $\mathrm{VI}$ & VII & $x$ & $x i$ & XIII \\
\hline \multirow[t]{2}{*}{1976} & 3 & 8 & - & 6,067 & 1,710 & 10,332 & 4,491 & 26,134 & 48,843 & - \\
\hline & 4 & 445 & - & 4,407 & 2,352 & 1,444 & 2,113 & 1,506 & 2,336 & - \\
\hline \multirow[t]{4}{*}{1977} & 1 & 1,965 & 8,886 & 48 & 1,179 & - & - & 1,245 & - & 一 \\
\hline & 2 & 35 & 2,675 & 1,183 & 2,408 & 1.777 & 127 & 1,055 & 15,403 & 一 \\
\hline & 3 & 16 & - & 3,224 & 2,913 & 13,655 & 3,986 & 13,444 & 51,126 & - \\
\hline & 4 & 15 & - & 1,694 & 2,903 & 1,097 & 2,310 & 6,764 & 1,417 & - \\
\hline \multirow[t]{4}{*}{1978} & 1 & 1,951 & 10,359 & - & 7 & - & 1,063 & 2,553 & - & - \\
\hline & 2 & 132 & 189 & 940 & 787 & 1,025 & 9 & 1,426 & 5,568 & - \\
\hline & 3 & - & - & 2,423 & 8,665 & 4,500 & 41 & 27,130 & 27,190 & - \\
\hline & 4 & 19 & - & 4,647 & 1,044 & 1,023 & 565 & 8,549 & 1,053 & - \\
\hline \multirow[t]{4}{*}{1979} & 1 & 1,011 & 6,497 & - & 551 & $\ldots$ & 10 & 3,311 & - & - \\
\hline & 2 & 90 & 53 & 31 & 1,101 & 1,697 & - & 1,482 & 4,040 & - \\
\hline & 3 & 54 & - & 16,895 & 3,049 & 12,339 & 1,243 & 25,061 & 13,937 & - \\
\hline & 4 & 76 & 36 & 52 & 3,307 & 3,546 & 3,264 & 11,821 & 591 & 830 \\
\hline \multirow[t]{4}{*}{1980} & 1 & 997 & 9,905 & 1 & 1 & - & - & 787 & 1,021 & 8,127 \\
\hline & 2 & 145 & 494 & 1,303 & 1,303 & 1,515 & 91 & 135 & 18,235 & - \\
\hline & 3 & + & 8,807 & 3,892 & 3,892 & 19,819 & 15,232 & 11,195 & 79,056 & - \\
\hline & 4 & + & 3,618 & 424 & 424 & 3,535 & 4,837 & 2,852 & 819 & 2,522 \\
\hline \multirow[t]{4}{*}{1981} & 1 & 661 & 3,990 & 40 & 40 & - & - & 1,368 & - & 13,899 \\
\hline & 2 & 8 & 681 & 391 & 391 & 2,225 & 943 & 412 & 8,342 & 2,166 \\
\hline & 3 & 4 & 3,405 & 2,746 & 2,746 & 17,893 & 14,738 & 14,949 & 57,125 & - \\
\hline & 4 & - & 313 & 417 & 417 & 5,060 & 10,101 & 3,735 & 2,283 & 5,925 \\
\hline \multirow[t]{4}{*}{1982} & 1 & 1,305 & 1,545 & + & + & - & - & 72 & - & 3,360 \\
\hline & 2 & 45 & 71 & 327 & 327 & 530 & - & 535 & 485 & 2,990 \\
\hline & 3 & + & 338 & 1,748 & 1,748 & 9,085 & 6,142 & 20,132 & 37,087 & - \\
\hline & 4 & 2 & 3,068 & 432 & 432 & 3,132 & 1,458 & 4,844 & 8,092 & 1,968 \\
\hline \multirow[t]{4}{*}{1983} & 1 & 9 & 1,183 & 6 & 6 & 78 & - & 2,125 & - & 6,161 \\
\hline & 2 & 6 & 575 & 195 & 195 & 912 & 17 & 133 & 5,355 & 97 \\
\hline & 3 & + & 134 & 1,175 & 1,175 & 10,263 & 1,513 & 8,274 & 65,439 & - \\
\hline & 4 & 3 & 968 & 170 & 170 & 3,182 & 629 & 16,548 & 83,732 & 4,099 \\
\hline \multirow[t]{4}{*}{1984} & 1 & 16 & 4,249 & 236 & 236 & 1,058 & 285 & 2,108 & - & 2,237 \\
\hline & 2 & 62 & 1.425 & 131 & 131 & 398 & 45 & 8 & 2,333 & - \\
\hline & 3 & + & 973 & 1,867 & 1,867 & 10,274 & 2,924 & 5,400 & 6.173 & - \\
\hline & 4 & 15 & 2,388 & 742 & 742 & 1,441 & 1,223 & 3,290 & 2,129 & - \\
\hline
\end{tabular}

* Annual landings since 1980 have been reported jointly. The totals were divided equally between regions IV and $V$ for this tabulation. 


\section{Results}

\section{Tag release and recovery data}

In 1980-82 106,241 herring $(57,959$ juveniles, 23,715 adults, and 24,567 mixed) were tagged and released at 38 sites (Table 2). The overall total and effective recovery rates were 5.2 and $3.7 \%$ while those for juveniles were 4.9 and $3.8 \%$ and for adults 4.9 and $3.2 \%$. A grand total of 164,128 herring $(99,323$ juveniles, 35,438 adults, and 29,367 mixed) were tagged and released between 1976-82. These taggings were performed on summer-feeding juveniles and adults, autumn-migrating juveniles and adults, overwintering juveniles, and spawning adults. No spring migrating fish were encountered. Total and effective recovery rates for all taggings conducted beween 1976 and 1982 were 5.9 and $4.1 \%$ for juveniles and 4.9 and $3.5 \%$ for adults. The grand total for total and effective recoveries was 6.0 and $3.9 \%$ respectively.

\section{Length, age, sex, maturity}

The length frequency composition, age structure, sex ratio, and maturity stages of juveniles and adult herring obtained from taggings of similar seasonal behavior categories combined by region and by year (1980-82) are presented in Table 3. Mean lengths reported for the various seasonal behavior categories were 14.8-19.6 cm (summer-feeding juveniles), $25.2-29.4 \mathrm{~cm}$ (summer-feeding adults), $25.5 \mathrm{~cm}$ (autumn-migrating adults), and 27.1-31.3 (spawning adults).

The majority of summer-feeding juveniles were age 2. Summer-feeding juveniles tagged during 1980 in region $V$ and $V I$ had a high percent of age 3 fish. The majority of summer-feeding and autumn-migrating adults were age 3 fish but large percentages of age 4,5 and $6+$ fish were found in some samples. Spawning fish were predominantly age 4 .

The sex ratio of adult fish was approximately $1: 1$ although females slightly outnumbered males in most cases. One group of autumn-migrating adults (region VII, 1980), contained significantly more females.

Relatively large percentages of ripe fish $(26.5 \%$, $1981 ; 70.0 \%, 1982)$ and spawning fish $(10.0 \%, 1982)$ were found in samples of late summer-feeding adults tagged in region VII. Samples of spawning fish were also obtained from taggings conducted in region IV (Hampton Shoal Ledges and the mouth of the Merrimac River, New Hampshire - inshore Jeffreys Ledge area) and region $X$ (the Perry Shore, Passamaquoddy Bay).

TABLE 2. Summary of tag release and recovery data for juveniles $(J)$, adults $(A)$, and mixed groups $(M)$, of herring by seasonal behavior category, region, and year (1980-82) including summaries for the period 1976-78 and 1976-82.

\begin{tabular}{|c|c|c|c|c|c|c|c|c|c|c|c|c|c|}
\hline \multirow[b]{2}{*}{ Region } & \multirow[b]{2}{*}{ Year } & \multicolumn{3}{|c|}{$\begin{array}{l}\text { Number of } \\
\text { release sites }\end{array}$} & \multicolumn{3}{|c|}{$\begin{array}{l}\text { Total number of } \\
\text { tagged fish }\end{array}$} & \multicolumn{3}{|c|}{$\begin{array}{l}\text { Percent total } \\
\text { recoveries }\end{array}$} & \multicolumn{3}{|c|}{$\begin{array}{l}\text { Percent effective } \\
\text { recoveries }\end{array}$} \\
\hline & & J & A & $M$ & J & A & $M$ & J & $A$ & $M$ & $J$ & A & $M$ \\
\hline \multicolumn{14}{|c|}{ Summer feeding } \\
\hline \multirow[t]{3}{*}{ v } & 1980 & 2 & - & - & 5,850 & - & - & 4.1 & - & - & 4.1 & - & 一 \\
\hline & 1981 & 3 & - & - & 8,995 & - & - & 2.6 & - & - & 2.3 & - & - \\
\hline & 1982 & 1 & - & - & 2,992 & - & - & 25.3 & - & - & 24.0 & - & - \\
\hline \multirow[t]{2}{*}{ VI } & 1980 & 2 & 2 & 2 & 5,419 & 4,343 & 3,737 & 3.2 & 11.7 & 1.6 & 2.6 & 6.5 & 0.6 \\
\hline & 1981 & 5 & $\ldots$ & - & 16,589 & - & - & 4.4 & - & - & 3.2 & - & - \\
\hline \multirow[t]{3}{*}{ VII } & 1980 & - & 1 & 4 & - & 2,344 & 10,187 & - & 6.4 & 9.2 & - & 6.1 & 7.2 \\
\hline & 1981 & 3 & 2 & - & 8,479 & 8,348 & - & 2.0 & 4.0 & - & 1.6 & 2.5 & - \\
\hline & 1982 & - & 1 & - & - & 2,000 & - & - & 2.6 & - & - & 2.2 & - \\
\hline \multirow[t]{2}{*}{$x$} & 1981 & 1 & - & - & 4,949 & - & - & 3.5 & - & - & 2.5 & - & - \\
\hline & 1982 & 1 & - & - & 4,686 & - & - & 7.4 & - & - & 2.9 & - & - \\
\hline \multicolumn{14}{|c|}{ Autumn migrations } \\
\hline IV & 1980 & - & - & 1 & - & - & 1,094 & - & - & 16.9 & - & - & 2.9 \\
\hline V & 1980 & - & - & 2 & - & - & 5,921 & - & - & 4.8 & - & - & 1.9 \\
\hline VII & 1980 & - & 1 & 1 & - & 4,998 & 3,628 & - & 1.3 & 1.1 & - & 0.9 & 0.8 \\
\hline \multicolumn{14}{|c|}{ Spawning } \\
\hline IV & 1980 & - & 2 & - & - & 990 & - & - & 1.4 & - & - & 1.0 & - \\
\hline $\mathrm{x}$ & 1980 & - & 1 & - & - & 692 & - & - & 4.2 & - & - & 3.2 & - \\
\hline \multirow{2}{*}{\multicolumn{2}{|c|}{$\begin{array}{l}\text { Totals (1980-82) } \\
\text { Overall Totals }\end{array}$}} & 18 & 10 & 10 & 57,959 & 23,715 & 24,567 & 4.9 & 4.9 & 6.1 & 3.8 & 3.2 & 3.8 \\
\hline & & & 38 & & & 106,241 & & & 5.2 & & & 3.7 & \\
\hline \multirow{2}{*}{\multicolumn{2}{|c|}{$\begin{array}{l}\text { Total }(1976-78)^{a} \\
\text { Overall Totals }\end{array}$}} & 23 & 7 & 4 & 41,364 & 11,723 & 4,800 & 7.2 & 5.0 & 15.3 & 4.6 & 4.2 & 3.7 \\
\hline & & & 34 & & & 57,887 & & & 7.4 & & & 4.4 & \\
\hline \multirow{2}{*}{\multicolumn{2}{|c|}{$\begin{array}{l}\text { Total (1976-82) } \\
\text { Grand Totals }\end{array}$}} & 41 & 17 & 14 & 99,323 & 35,438 & 29,367 & 5.9 & 4.9 & 7.6 & 4.1 & 3.5 & 3.8 \\
\hline & & & 72 & & & 164,128 & & & 6.0 & & & 3.9 & \\
\hline
\end{tabular}

Reported in Creaser et al., 1984 
TABLE 3. Length and age frequency and sex and maturity compositions (\%) of juvenile and adult herring sampled during tagging operations in regions IV-X along the Maine and New Hampshire coasts during 1980-82.

\begin{tabular}{|c|c|c|c|c|c|c|c|c|c|c|c|c|c|c|}
\hline \multicolumn{8}{|c|}{ Summer feeding juveniles } & \multicolumn{4}{|c|}{ Summer feeding adults } & $\begin{array}{l}\text { Autumn- } \\
\text { migrating } \\
\text { adults }\end{array}$ & \multicolumn{2}{|c|}{ Spawning } \\
\hline \multicolumn{3}{|c|}{ V } & \multicolumn{2}{|c|}{ VI } & VII & \multicolumn{2}{|c|}{$x$} & $\mathrm{~V} !$ & \multicolumn{3}{|c|}{ VII } & VII & IV & $x$ \\
\hline 1980 & 1981 & 1982 & 1980 & 1981 & 1981 & 1981 & 1982 & 1980 & 1980 & 1981 & 1982 & 1980 & 1980 & 198 \\
\hline
\end{tabular}

\begin{tabular}{|c|c|c|c|c|c|c|c|c|c|c|c|c|c|c|c|}
\hline \multicolumn{16}{|c|}{0.5} \\
\hline \multicolumn{16}{|l|}{11} \\
\hline 12 & & & & & & 2.4 & & & & & & & & & \\
\hline 13 & & & 2.0 & & 2.8 & 6.1 & 6.0 & & & & & & & & \\
\hline 14 & 5.5 & 0.7 & 64.0 & & 16.0 & 11.5 & 14.0 & & & & & & & & \\
\hline 15 & 13.0 & 22.7 & 20.0 & & 22.4 & 13.3 & 16.0 & & & & & & & & \\
\hline 16 & 22.0 & 19.3 & 2.0 & 5.0 & 17.6 & 21.2 & 28.0 & & & & & & & & \\
\hline 17 & 21.5 & 16.7 & 2.0 & 19.0 & 16.8 & 15.8 & 14.0 & 10.0 & & & & & & & \\
\hline 18 & 14.5 & 12.0 & & 24.0 & 12.4 & 13.3 & 18.0 & 22.0 & & 0.6 & & & & & \\
\hline 19 & 10.0 & 12.7 & & 12.0 & 6.4 & 9.1 & 4.0 & 36.0 & & 0.6 & 0.9 & & & & \\
\hline 20 & 5.5 & 11.3 & & 18.0 & 4.8 & 4.8 & & 16.0 & 0.4 & 1.2 & 0.9 & & & & \\
\hline 21 & 2.0 & 4.0 & & 10.0 & 0.4 & 2.4 & & 10.0 & 2.6 & & 0.9 & & & & \\
\hline 22 & 3.5 & 0.7 & & 5.0 & 0.4 & & & 2.0 & 3.5 & 1.8 & & & 4.0 & & \\
\hline 23 & 1.0 & & & 4.0 & & & & 4.0 & 14.6 & 6.1 & 6.4 & & 8.0 & & \\
\hline 24 & 0.5 & & & 1.0 & & & & & 18.9 & 6.7 & 8.2 & 4.0 & 26.0 & & 4.0 \\
\hline 25 & & & & 2.0 & & & & & 25.1 & 9.1 & 14.5 & 4.0 & 26.0 & 0.6 & 22.0 \\
\hline 26 & & & & & & & & & 20.7 & 12.1 & 13.6 & 20.0 & 12.0 & 1.3 & 30.0 \\
\hline 27 & & & & & & & & & 9.3 & 20.6 & 12.7 & 14.0 & 22.0 & 2.6 & 24.0 \\
\hline 28 & & & & & & & & & 3.1 & 21.2 & 17.3 & 6.0 & 2.0 & 10.9 & 10.0 \\
\hline 29 & 0.5 & & & & & & & & 0.4 & 11.5 & 12.7 & & & 23.1 & 4.0 \\
\hline 30 & & & & & & & & & 1.3 & 4.8 & 5.5 & 12.0 & & 10.9 & \\
\hline 31 & & & & & & & & & & 1.2 & 4.5 & 16.0 & & 13.5 & 4.0 \\
\hline 32 & & & & & & & & & & 1.2 & 0.9 & 16.0 & & 12.8 & \\
\hline 33 & & & & & & . & & & & 0.6 & & 8.0 & & 7.1 & \\
\hline 34 & & & & & & & & & & & & & & 8.3 & \\
\hline 35 & & & & & & & & & & 0.6 & 0.9 & & & 3.8 & 2.0 \\
\hline 36 & & & & & & & & & & & & & & 2.6 & \\
\hline 37 & & & & & & & & & & & & & & 1.9 & \\
\hline \multicolumn{16}{|l|}{38} \\
\hline 39 & & & & & & & & & & & & & & 0.6 & \\
\hline Total & 200 & 150 & 50 & 100 & 250 & 165 & 50 & 50 & 227 & 165 & 110 & 50 & 50 & 156 & 50 \\
\hline Mean & 17.7 & 17.7 & 14.8 & 19.6 & 16.7 & 16.8 & 16.4 & 19.6 & 25.2 & 27.2 & 27.2 & 29.4 & 25.5 & 31.3 & 27.1 \\
\hline \multicolumn{16}{|c|}{ B. Age (years) } \\
\hline \multicolumn{16}{|l|}{1} \\
\hline 2 & 72.0 & 98.9 & 100.0 & 62.9 & 98.7 & 98.9 & 100.0 & 93.3 & 10.0 & 4.0 & 10.0 & & & & \\
\hline 3 & 26.0 & 1.1 & & 34.3 & 1.3 & 1.1 & & 6.7 & 83.3 & 48.0 & 36.7 & 40.0 & 66.7 & 6.7 & 20.0 \\
\hline 4 & 2.0 & & & 2.9 & & & & & 6.7 & 44.0 & 31.7 & 3.3 & 33.3 & 70.0 & 73.3 \\
\hline 5 & & & & & & & & & & & 16.7 & 36.7 & & 13.3 & 3.3 \\
\hline $6+$ & & & & & & & & & & 4.0 & 5.0 & 20.0 & & 10.0 & 3.3 \\
\hline Total & 50 & 90 & 30 & 35 & 150 & 91 & 30 & 30 & 30 & 25 & 60 & 30 & 15 & 30 & 30 \\
\hline \multicolumn{16}{|c|}{ C. Sex composition } \\
\hline Male & & & & & & & & & 47.8 & 50.0 & 46.9 & 48.0 & 39.6 & 46.7 & 50.0 \\
\hline Female & & & & & & & & & 52.2 & 50.0 & 53.1 & 52.0 & 60.4 & 53.3 & 50.0 \\
\hline Total & & & & & & & & & 67 & 46 & 98 & 50 & 48 & 30 & 50 \\
\hline \multicolumn{16}{|c|}{ D. Maturity stage } \\
\hline \multicolumn{16}{|c|}{1 Immature } \\
\hline $2 \mathrm{Imma}$ & & & & & & & & & 89.6 & 50.0 & 45.9 & 14.0 & 66.7 & & 12.0 \\
\hline 3 Devel & & & & & & & & & 6.0 & 23.9 & 2.0 & & & & \\
\hline 4 Devel & & & & & & & & & 1.5 & 21.7 & 18.4 & 4.0 & & & \\
\hline 5 Ripe & & & & & & & & & 1.5 & 4.3 & 26.5 & 70.0 & 2.1 & 6.7 & \\
\hline 6 Spaw & & & & & & & & & 1.5 & & 4.1 & 10.0 & & 93.3 & 66.0 \\
\hline 7 Spent & & & & & & & & & & & 2.0 & 2.0 & 10.4 & & 20.0 \\
\hline 8 Reco & & & & & & & & & & & 1.0 & & 20.8 & & 2.0 \\
\hline Total & & & & & & & & & 67 & 46 & 98 & 50 & 48 & 30 & 50 \\
\hline
\end{tabular}

\section{Migration patterns}

Recovery information from all juvenile and adult seasonal behavior categories tagged in all regions during 1976-82 are presented in Tables 4-8. Some of the adjusted numbers of recoveries from the 1976-78 data in Tables 4, 5, and 6, do not correspond with unadjusted recoveries from 1976 to 1978 data presented in Creaseret al. (1984). The reason for this is that, based upon the catches reported in Table 1, we reevaluated tag recoveries originally reported from Gloucester, Mass. (region IV) and decided the fish were usually caught in region III and unloaded in Gloucester.

Summer-feeding juveniles tagged in regions $\mathrm{V}, \mathrm{VI}$, VII, and $X$ (Table 4) frequently moved into adjacent regions during the 3 rd and 4 th quarters. Some fish 
TABLE 4. Ratio of tag recoveries per 1,000 metric tons of fish caught by region and calendar quarter from summer-feeding juveniles tagged in regions $V$, $V I, V I I$, and $X$ during 1976-81. (Encircling lines indicate hypothesised migration patterns, with dashed lines and question marks indicating increased uncertainty in interpretation.)

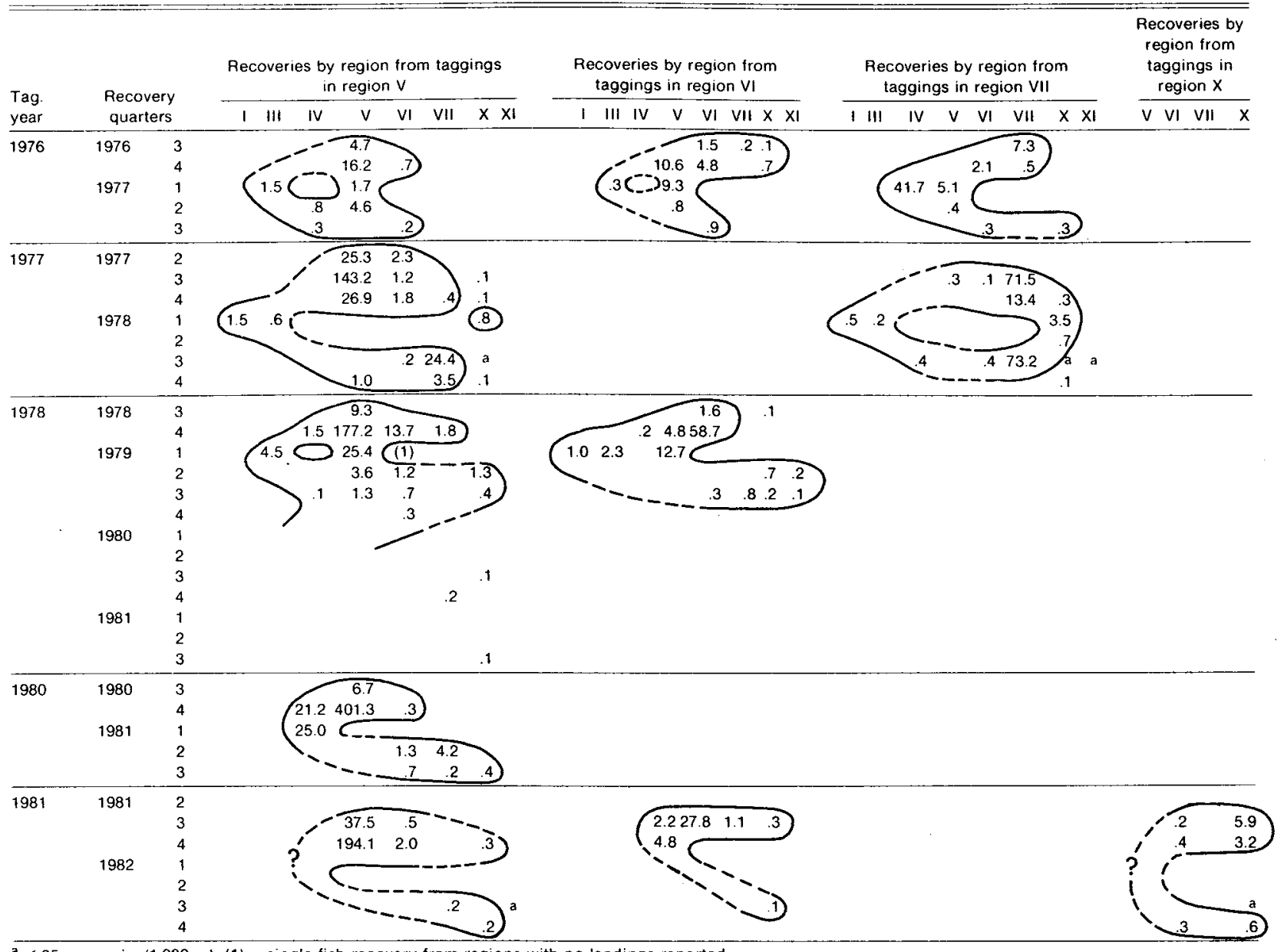

a $<.05$ recoveries $/ 1,000 \mathrm{mt}$. (1) $=$ single fish recovery from regions with no landings reported.

tagged in regions $\mathrm{V}, \mathrm{VI}$, and $\mathrm{VII}$ then underwent an autumn migration to the southwest where they overwintered in regions I, III, IV, and V during the 1st quarter of recovery. Recovery rates from region I and III at this time, were generally not as great as those from regions IV and $V$ and many fish tagged in regions $V I$ and $V I I$ moved only as far as regions IV and $V$. Recoveries from the 1976 and 1978 taggings in region $V$ show that a larger percentage of fish overwintered in region $V$ than in region III. Occurrence of a juvenile overwintering area in region $V$ is confirmed by taggings in region $V$ (Table 7) which show recoveries in this same region throughout the 1st and 2nd quarters of recovery. It is evident from taggings in region $V$ (Table 4 ), that the recovery rate of overwintering fish from region $V$ during the 1st quarter of recovery was quite variable; no recoveries being reported during some tagging years (1977, $1980,1981)$ and some recoveries reported during other years $(1976,1978)$. The 1977 taggings in regions $V$ and VII (Table 4) show that some fish also overwintered in region $X$. It is also evident from the 1977, 1980, 1981 data in region $V$ and the 1978 data in region $V I$, that tagged fish appeared east of the tagging site during the 2nd and 3rd quarters of the following year.

Summer-feeding adults tagged in regions IV, VI, and VII (Table 5) became widely dispersed along the Maine coast during the 3 rd and 4th quarter preceding their autumn migrations to the southwest. Fish tagged as summer-feeding adults in region VII were consistently found overwintering in regions I and III during the 1st quarter of recovery. When overwintering occurred in region IV during the 1st quarter of recovery (tagging years 1976,1980 ), the recovery rate was generally quite high. In one instance (tagging year 1977), some adults tagged in region $V I I$ overwintered in region $X$. Fish from the 1976 and 1977 taggings in region VII began moving to the northeast during the 2nd quarter of the following year. By the 3rd quarter, these fish were again widely distributed along the Maine coast within regions $V-X$. There was a small, but consistent, tendency for some adult fish tagged in eastern Maine (region VII) to be 
TABLE 5. Ratio of tag recoveries per 1,000 metric tons of fish caught by region and calendar quarter from summer-feeding adults tagged in regions IV, Vi, and VII during 1976-82. (Encircling lines indicate hypothesised migration patterns, with dashed lines indicating increased uncertainty in interpretation.)

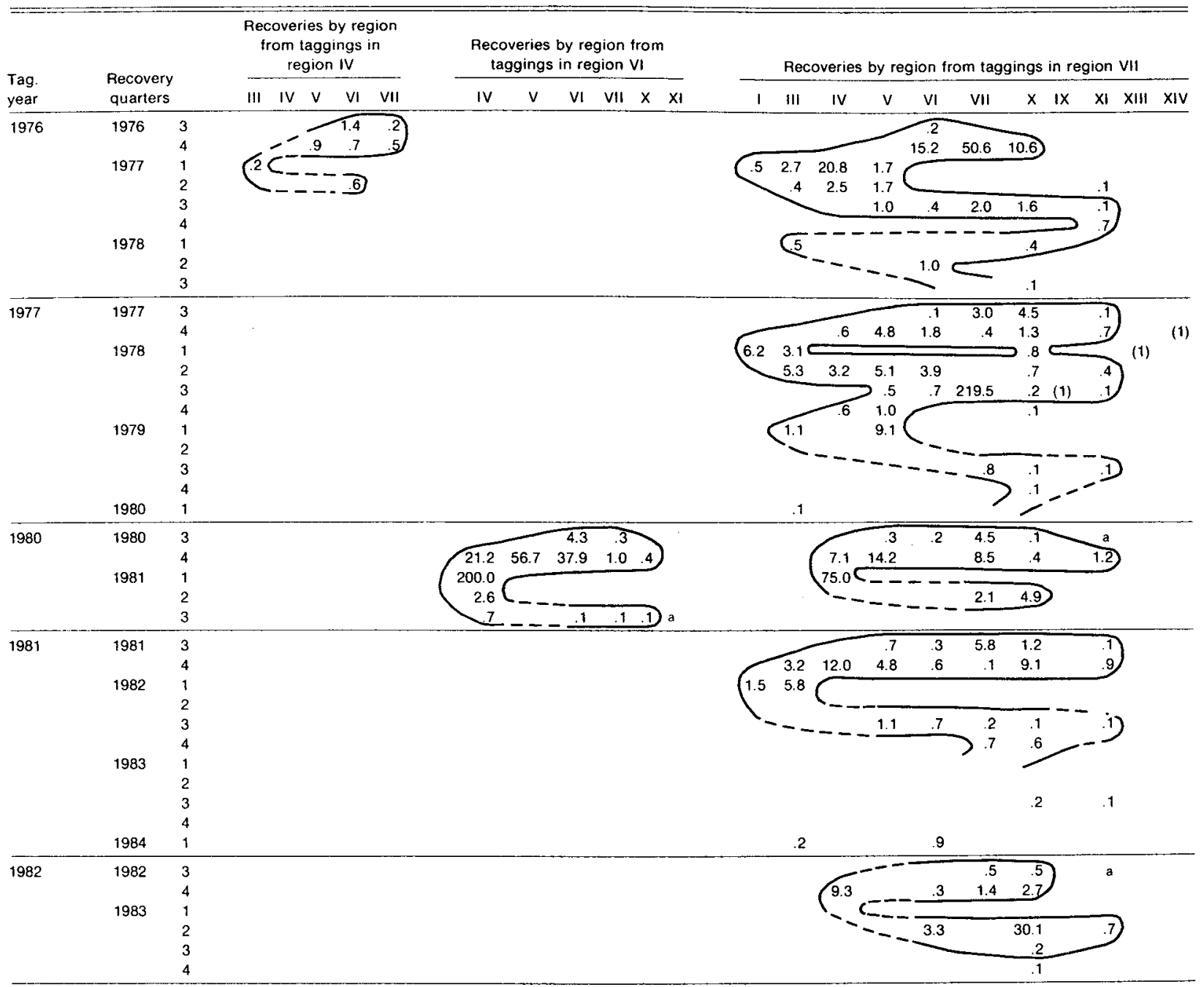

a $<.05$ recoveries $/ 1,000 \mathrm{mt}$. $(1)=$ single fish recovery from regions with no landings reported.

recovered in the Southwest Nova Scotia fishery (region XI). Single recoveries from the 1977 tagging studies, were also reported from Chedabucto Bay (region XIII) and Sydney Bight (region XIV).

Autumn-migrating juveniles (Table 6A) were tagged in region $V$ during the 4 th quarters of 1976 and 1977 while migrating to overwintering grounds in regions I and III. These juveniles moved eastward during the following 2 nd quarter and dispersed themselves over summer-feeding areas which were east of the regions in which they were tagged. Autumn-migrating adults (Table $6 \mathrm{~B}$ ) were tagged in region VII during the 4th quarter of 1980 while migrating to overwintering grounds in region IV. These fish also moved east during the 2nd quarter of the following year and dispersed themselves over summer-feeding areas in regions V-XI.
Most recoveries from overwintering juveniles tagged in region $X$ were from region $X$ throughout the period recoveries were reported (Table 7). An occasional recovery was reported from the overwintering grounds in regions I and IV.

Although relatively few spawners were tagged (990 in region IV, 692 in region $X$ ) and few recoveries reported, the results suggest that spent fish overwintered in region III during the 1st quarter and during the following 3 rd and 4 th quarters the fish were in close proximity to the tagging area (Table 8 ).

\section{Discussion}

The overall seasonal migration patterns of herring tagged as summer-feeding juveniles (Table 4) and 
TABLE 6. Ratio of tag recoveries per 1,000 metric tons of fish caught by region and calendar quarter from (A) autumn-migrating juveniles tagged in region $V$ during 1976 and 1977 and (B) autumn-migrating adults tagged in region VII during 1980. (Encircling lines indicate hypothesised migration patterns, with dashed lines indicating increased uncertainty in interpretation.)

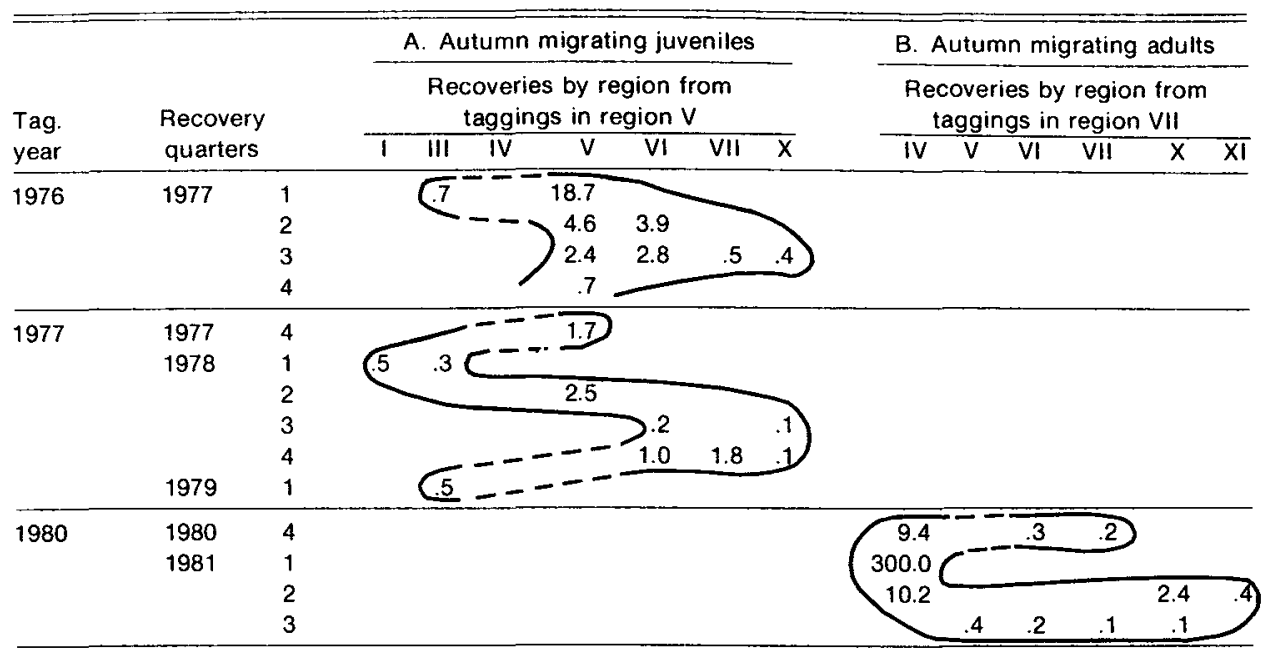

TABLE 7. Ratio of tag recoveries per 1,000 metric tons of fish caught by region and calendar quarters from overwintering juveniles tagged in regions $V$ and $X$ during 1977, 1978 and 1982. (Encircling lines indicate hypothesised migration patterns, with dashed lines indicating increased uncertainty in interpretation.)

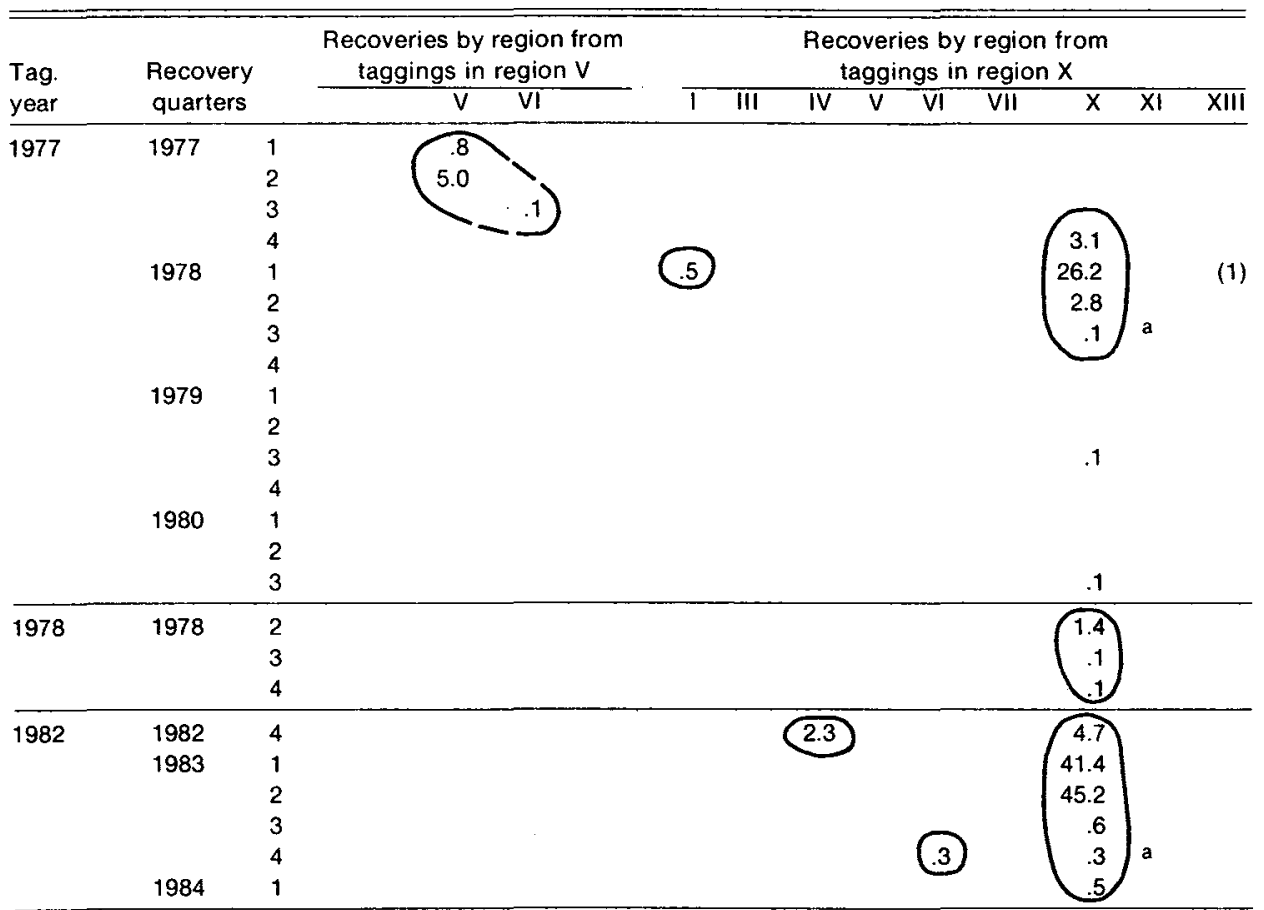

a $<.05$ recoveries $/ 1,000 \mathrm{mt} .(1)=$ single fish recovery from regions with no landings reported.

summer-feeding adults (Table 5) have remained relatively unchanged throughout the study period. A comparison of recovery information from summer-feeding juveniles tagged in regions $\mathrm{V}, \mathrm{VI}, \mathrm{VII}$ (Table 4) with recovery information from summer-feeding adults in region VII (Table 5), where taggings were performed in the same region over at least 2 years, shows that fish tagged as juveniles were infrequently recaptured in region $I$ and never recaptured beyond region $X$ whereas adults were frequently recaptured in region I and consistently recaptured as far east as Southwest Nova Scotia (region XI). Adult herring, therefore, appear to swim 
TABLE 8. Ratio of tag recoveries per 1,000 metric tons of fish caught by region and calendar quarters from spawning adults tagged in regions IV and $X$ during 1980. (Encircling lines indicate hypothesised migration patterns, with dashed lines indicating increased uncertainty in interpretation.)

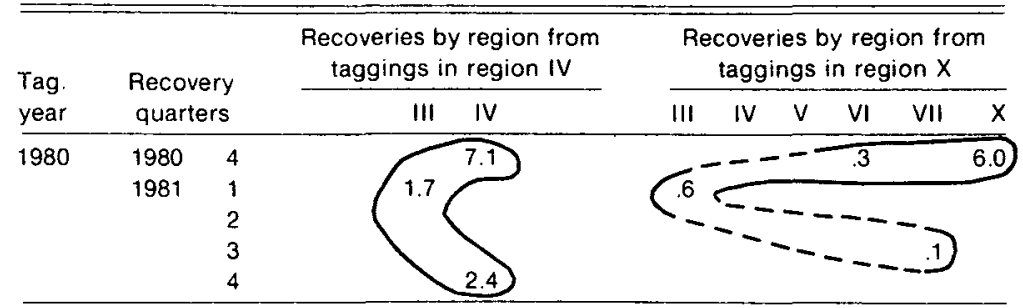

longer distances or have a greater migratory range. They are also recaptured in more regions simultaneously during the 3rd and 4th quarters of recovery when spawning occurs. This suggests that schools tagged as summer-feeding adults may disperse over a wider feeding range or may consist of a mixture of stocks. Sinclair et al. (1985) describes Northwest Atlantic herring as "highly migratory 'interwoven' populations" although they are more discrete during the spawning period. Various degrees of emigration and immigration from adjacent and further removed populations have also been reported by Haegele (1981). A comparison of Tables 4 and 5 also suggests that fish tagged as adults in region VII are more likely to be recovered over a longer period of time. Apparently, adult herring either retain their tags longer or they are less susceptible to tag-induced mortality.

Some herring tagged as summer-feeding juveniles (age 2) were recovered overwintering in regions 1,111 , and IV during the 1st quarter of recovery (at age 3) (Table 4). Many adult fish also overwintered in the same regions at the time (Tabie 5). These results suggest that older juveniles (age 3 ) are assuming migratory habits similar to adults and regions I, III and IV appear to be major overwintering grounds for both. Canadian taggings of summer-feeding adults in regions $X$ and $X I$ also revealed some overwintering in regions $I$ and III (Stobo, 1983). Regions I and III appear to be the site of some mixing of adult stocks from Jeffrey's Ledge and Great South Channel (Almeida and Burns, MS 1978; Waring, MS 1981) to Southwest Nova Scotia (Stobo, 1983) during the winter. Tables 4 and 5 also show that differences existed in tag recovery rates from overwintering regions (the 1 st quarter of recovery) between years. This probably reflects yearly differences in both availability and exploitation of herring within the overwintering regions. The lack of movement recorded for most of the herring tagged as overwintering juveniles in region $X$ (Table 7 ) probably occurs because the overwintering area and the summer-feeding area are in the same region.

All of the adult taggings conducted in region VII (Table 5) yielded recoveries from regions $V I I, X$, and $X I$ during the spawning season (the 3 rd and 4 th quarter of recovery). These three regions are known to contain spawning grounds along the Cutler-Lubec shore of the Grand Manan Channel (D. A. Clifford, 1982. Maine Department of Marine Resources, Augusta, Maine, pers. comm.; Stevenson, MS 1984), Grand Manan Island (Iles and Sinclair, 1982) and Southwest Nova Scotia (Stobo, MS 1982) respectively.

A relatively small number of spawning herring were tagged in regions IV and $X$ during 1980, (Table 8 ). Spawning herring were tagged in region IV at Hampton Shoal Ledges and the mouth of the Merrimac River in close proximity to the known spawning ground on Jeffrey's Ledge (Sindermann, 1979). Although the spawning herring tagged in region $X$ (Perry Shore, Passamaquoddy Bay) were captured in a region where they are not normally found (Graydon Ritchie, 1980, Perry Shore weir fisherman, Perry, Maine, pers. comm.), they are in close proximity to known spawning grounds in region X off Grand Manan Island (Iles and Sinclair, 1982) and region VII in the vicinity of Cross Island, Cutler, Maine (Bigelow and Schroeder, 1953) and it is probable that they would have spawned in either one of these spawning grounds had they not been confined in commercial fishing gear. Recoveries from these taggings approximately 1 year later were in close proximity to the areas where these fish were tagged.

\section{Acknowledgements}

The combined efforts of many people were responsible for the successful completion of these tagging studies. We are indebted to the fishermen who supplied the fish for tagging, laboratory personnel for tagging assistance, fish packers who retrieved the tags, and other processing facility personnel and Canadian and U.S. government employees who accumulated tags, recorded tag numbers, recovery dates and locations, and mailed this information to us. Special appreciation is extended to Margaret Hunter for computer programming assistance, Curt Crosby and Terry Cucci for their major roles in tagging and data entry, Jean Chenoweth for length, weight, age, sex, and maturity analysis of tagging samples, James Rollins for photographic servi- 
ces, and Pamela Mancuso for typing. Taggings conducted during 1976-78 were supervised by Garret D. Speirs (D.M.R.). Taggings of adult fish conducted during 1980 were supervised by Stanley B. Chenoweth (D.M.R.). Funding was provided by the Maine Sardine Council and the New England Regional Fishery Management Council.

\section{References}

ALMEIDA, F. P., and T. S. BURNS. MS 1978. Preliminary results of the international herring tagging program conducted on the northeast coast of the United States in 1977. U. S. Nat. Mar. Fish. Serv., Northeast Fisheries Center, Woods Hole Lab. Ref. Doc., No. 78-7, 10 p.

BIGELOW, H. B., and W. C. SCHROEDER, 1953. Fishes of the Gulf of Maine. Fish. Bull. U.S., 53: 577 p.

BOYAR, H. C. 1968. Age, length and gonadal stages of herring from Georges Bank and the Gulf of Maine. ICNAF Res. Bull., 5: 49-61.

CREASER, E. P., D. A. LIBBY, and G. D. SPEIRS. 1984. Seasonal movements of juvenile and adult herring. Clupea harengus L., tagged along the Maine coast. J. Northw. AtI. Fish. Sci., 5: 71-78.

CREASER, E. P., and D. A. LIBBY. 1986. Tagging of age 1 herring (Clupea harengus $L$.) and their movement along the Maine and New Brunswick coasts. J. Northw. Atl. Fish
Sci, 7: 43-46.

HAEGELE, C. W. 1981. Tagging of herring in British Columbia during the 1970-1980 herring season. Can. Ind. Rep. Fish. Aquat. Sci., 125: $20 \mathrm{p}$.

ILES, T. D., and M. SINCLAIR. 1982. Atlantic herring: stock discreteness and abundance. Science, Wash., 215: 627633

SINCLAIR, M., V. C. ANTHONY, T. D. ILES, and R. N O'BOYLE. 1985. Stock assessment problems in Atlantic herring (Clupea harengus) in the Northwest Atlantic. Can. J. Fish. Aquat. Sci., 42: 888-898.

SINDERMANN, C. J. MS 1979. Status of Northwest Atlantic herring stocks of concern to the United States. U.S. Nat. Mar. Fish. Serv. Tech.Rep., No. 23, 449 p.

STEVENSON, D. K. MS 1984. Spawning locations and times for Atlantic herring (Clupea harengus harengus L.) in coastal waters of eastern Maine. Maine Dept. Mar. Resour. Lab. Ref. Doc., No. 84-1, 26 p.

STOBO, W. T. MS 1982. Tagging studies on Scotian Shelf herring. NAFO SCR Doc., No. 108, Serial No. N617, 16 p. 1983. Report of the Ad hoc Working Group on Herring Tagging. NAFO Sci. Coun. Rep., 1983: 77-101.

TRANQUILLI, J. A., and W. F. CHILDERS. 1982. Growth and survival of largemouth bass tagged with Floy anchor tags. N. Amer. J. Fish Manag., 2: 184-187.

WARING, G. MS 1981. Results of the international herring tagging program conducted by USA in the Gulf of Maine. Georges Bank and contiguous waters from 1976-1978. NAFO SCR Doc., No. 122, Serial No. N428, 24 p. 